\title{
Spatial contamination and health risks of heavy metal(loid)s in surface soils from a petrochemical complex in the northeastern region of Algeria
}

\author{
Hayat Boudia ${ }^{\mathrm{a}}$, Laurent Vassalo ${ }^{\mathrm{b}}$, Mohammed Hadjel ${ }^{\mathrm{a}}$, \\ Pascale Prudent ${ }^{\mathrm{b}}$, Jean-Luc Boudenne ${ }^{\mathrm{b},{ }^{*}}$
}

${ }^{\text {a } U S T O-M B, ~ U n i v e r s i t e ́, ~ L S T G P, 31000 ~ O r a n, ~ A l g e ́ r i e ~}$

${ }^{\mathrm{b}}$ Aix Marseille Univ., CNRS, LCE Marseille, France

* Corresponding author. Address: Aix-Marseille University-CNRS, Faculty of Sciences, Department of Chemistry, Laboratory of Environmental Chemistry, 3 Place Victor Hugo Case 29, CS80249, F-13331 Marseille Cedex 03; Phone: (+33) (0)413551031; Fax: (+33) (0)413551060; e-mail: jean-luc.boudenne@univ-amu.fr

\begin{abstract}
The spatial distribution patterns, origins and environmental and health risks of metal trace elements ( $\mathrm{As}, \mathrm{Cd}, \mathrm{Co}, \mathrm{Cr}, \mathrm{Cu}, \mathrm{Ni}, \mathrm{Pb}, \mathrm{Zn}$ ) have been analyzed through the spiking and the analysis of 84 soils sampled in the region of Arzew (Algeria). This city gathers one of the biggest petroleum harbors of Algeria and gathers in the same platform several industries, coexisting with residential and agricultural areas. The mean concentration of all the metals studied exceed their corresponding backgrounds levels and/or exceed the ecological Predicted No effect Concentration (PNEC) values. The geo-accumulation and the potential ecological risk indices indicate a low to moderate risk for $\mathrm{As}, \mathrm{Co}, \mathrm{Cu}, \mathrm{Ni}$ and $\mathrm{Zn}$, and a moderate to considerable risk for $\mathrm{Cr}$ and $\mathrm{Pb}$. According to the health risk assessment results, the carcinogenic risks due to $\mathrm{Cr}$ exceed the acceptable level in all the functional areas, and when considering combined effects of metals, the hazard index obtained show a high potential carcinogenic risk to the local children.
\end{abstract}

Keywords: Heavy metal; spatial distribution; pollution assessment; health impact; urban soil

\section{Introduction}

Soil metal contamination is of great concern for human and environmental health, particularly in areas submitted to a concomitant increase in industrial activity and a growing population. This is particularly valid in places where expansion of industry has been chaotic resulting from an absence of planning, and where, today, dangerous undertakings are not separated 
from residential areas, school zones, agricultural areas, or either leisure activities. In such areas, Metal Trace Elements (MTE) are released partly from vehicular emissions (due to wear and tear of vehicle parts such as brake, tire and clutch), and partly from agricultural activities from excess use of amendments (e.g., sewage sludge and wastewater, animal manure, composts) or agrochemicals (e.g. fertilizers) (Solgi et al. 2018). Another important part of metal source in soils, after geochemical or natural background, comes from industrial activities, issued from smelting, mining, metal processing, dyes, pigments, ceramic, tanning, textile industries (Abraham et al. 2018), and from petrochemical industries.

Petrochemical industries have been identified as important emission sources of inorganic and organic pollutants that can pollute soils, both in close proximity of petroleum refining and petrochemical manufacturing plants (by improper disposal or bad treatment of effluents), and at distal areas through the waterborne transport of fine particulate metals, and together with windborne dispersal of dry fine particles, with a diffuse contamination gradient decreasing with distance from the source (Karim et al. 2015).

Elements such as cadmium $(\mathrm{Cd})$, chromium $(\mathrm{Cr})$, copper $(\mathrm{Cu})$, nickel $(\mathrm{Ni})$, lead $(\mathrm{Pb})$, vanadium $(\mathrm{V})$, zinc $(\mathrm{Zn})$, cobalt $(\mathrm{Co})$, manganese $(\mathrm{Mn})$, molybdenum $(\mathrm{Mo})$ and arsenic (As) among others, can be released to air and can thus be inhaled by workers but also by nonoccupationally exposed populations living in the neighbourhood. Once deposited, these elements can bioaccumulate in plants and animals and may eventually reach humans through the food chain via direct intake of heavy metals by plants from soils (Bermudez et al., 2011). Drinking waters are another mode of ingestion of MTE, especially in heavily polluted areas (Chen et al. 2018). Direct oral soil ingestion cannot be ignored: soil pica behaviour has been implicated in several case studies in which MTE exposure in children with elevated MTE levels in soils were correlated. After ingestion and inhalation, skin contact constitutes the third main way of human exposure to soil metals (Cao et al. 2018).

Even some metals such as $\mathrm{Co}, \mathrm{Cr}$ (III), $\mathrm{Cu}, \mathrm{Mn}, \mathrm{Mo}$ and $\mathrm{Zn}$ are considered as essential compounds for humans at low concentrations due to their roles in metabolic functions (Prashanth et al. 2015), and even $\mathrm{Ni}$ and $\mathrm{V}$ are supposed to have beneficial biological functions in plants and some animals, the continued exposure to low levels of MTE may lead to adverse health effects. According to the International Agency for Research on Cancer (IARC), As, Cd, Cr (VI) compounds and $\mathrm{Ni}$ are classified as carcinogenic, whereas $\mathrm{Co}, \mathrm{Pb}$ and $\mathrm{Sb}$ trioxide are considered as possibly carcinogenic (Mulware, 2013). The organs affected by these metals are kidney, lung, liver, gastrointestinal and haematological systems, mainly the peripheral and central nervous systems (Karri et al. 2018) though their entry into the food 
chain or by the inhalation of dust from contaminated surface soil (Tang et al. 2017). Moreover, exposure to MTE may produce additive or synergistic interactions or even new effects that are not seen in single component exposures (Kossowska et al. 2013).

Some epidemiological studies have also pointed out the possibility that living adjacent to petrochemical facilities could induce an excess of leukemia, as well as bone, brain, and bladder cancers and preterm deliveries (Barazza et al. 2018). However, the detailed pathogenic mechanisms remain unclear due to the complex mixture of pollutants emitted by the petrochemical industry, which include not only MTE but also sulfur oxides, nitrogen oxides, metals, polycyclic aromatic hydrocarbons, and volatile organic compounds (Kampeerawipakorn et al. 2017).

The region of Arzew is located between Stidia and Mostaganem towns in the Algerian shoreline of Mediterranean Sea (Figure 1), about $40 \mathrm{~km}$ east from the city of Oran and at 400 $\mathrm{km}$ West from Algiers. It constitutes one of the biggest petroleum harbours and many industrial complexes (gathering oil, gas, refining and petrochemical industries) are situated in this area making it an industrial and commercial hub for Algerian economy.

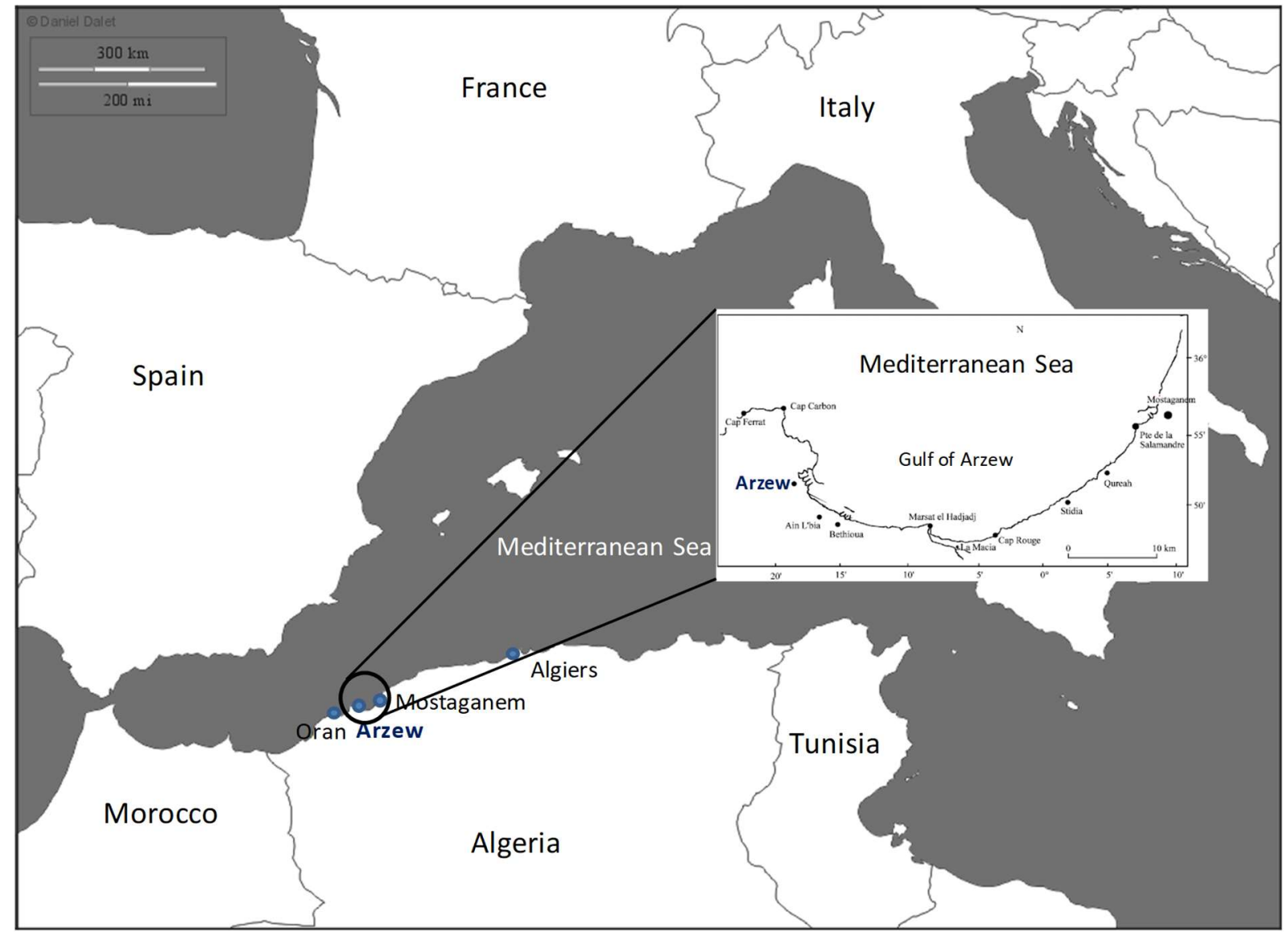

Figure 1: Location of Arzew along the Mediterranean coast

(issued from the background map made available free of charge by histgeo.ac-aix-marseille.fr) 
The first large-scale Liquefaction Natural Gas (LNG) plant in the world started began functioning in 1964 when LNG was transported from Arzew, Algeria to Canvey Island, with initial production capacity of 2560 metric tons a day of LNG (Tayeb et al. 2015). The industrial platform is spread over an area of 2500 ha. The pole consists of a large number of hydrocarbon and petrochemical plants, liquefaction natural gas, liquefied petroleum gas, a refinery, three units of ammonia and nitrogen fertilizers production, a methanol synthesis complex, an electricity generation plant, and a seawater desalination plant.

There are very limited published data on the soil contamination in Arzew, existing published studies being focused on the impacts of petrochemical activities on marine ecosystems (Dauvin et al. 2017), whereas a large part of MTE found in Gulf or Arzew come from inland (from leaching of soils, and by wet or dry atmospheric deposition). From an environmental and human health point of view (the petrochemical platform is surrounded by urban concentration of about 148,782 inhabitants), it seems thus important to monitor the impact of anthropogenic activities on heavy metal contamination of urban soil and for the development of proper management strategies for urban environment pollution control and for the remediation of heavy metal contaminated soils of Arzew city.

The main objectives of this study were thus to estimate the MTE concentrations in soils of Arzew and describing their distribution patterns according areas defined by human activities by use of pollution indices (geo-accumulation index and potential ecological risk index). Furthermore, it aimed at assessing the potential health risks associated with MTE for children living in this city, by calculation of hazard quotients for inhalation, dermal and ingestion exposures, and by the determination of resulting hazard index. This study intends thus to provide for the first-time results on the multi-contamination of soils of Arzew, where industrial and heavy road traffic activities coexist with agriculture and residential areas and intends to be useful for local authorities for the development of risk management measures.

\section{Materials and methods}

\subsection{Study Area}

The study site covers the Arzew petrochemical platform area, that covers a part of the two cities of Arzew and Aïn El Beya Bethioua impacted by the petrochemical activities and belonging to the Willaya of Oran. From a geological point of view, the site under study belongs to the Chelif Basin, located in the western part of the Tellian Atlas, taking the form of 
an elongated basin extending over $350 \mathrm{~km}$ in ENE-WSW direction (Figure 2a) and filled by Miocene to Pliocene series on Mesozoic and Paleogene substratum. This basin is a predominantly Neogene transtensional basin located within the Northern Algerian foothills, and takes part of the African margin and located southwest of the "Dorsale calcaire" which constitutes the surface expression of the paleosuture between exotic terranes of European affinities (Kabylides Crystalline Massifs and associated Mesozoic to Eocene sedimentary cover) and the Tellian allochthon. The Chelif basin consists of Mesozoic basinal units derived from the former passive margin of North Africa. The Neogene sedimentary infill of the Chelif Basin rests on top of allochthonous basinal Mesozoic to Paleogene shales, carbonates and sandstone units of the southern Tellian allochthon (Arab et al. 2015).

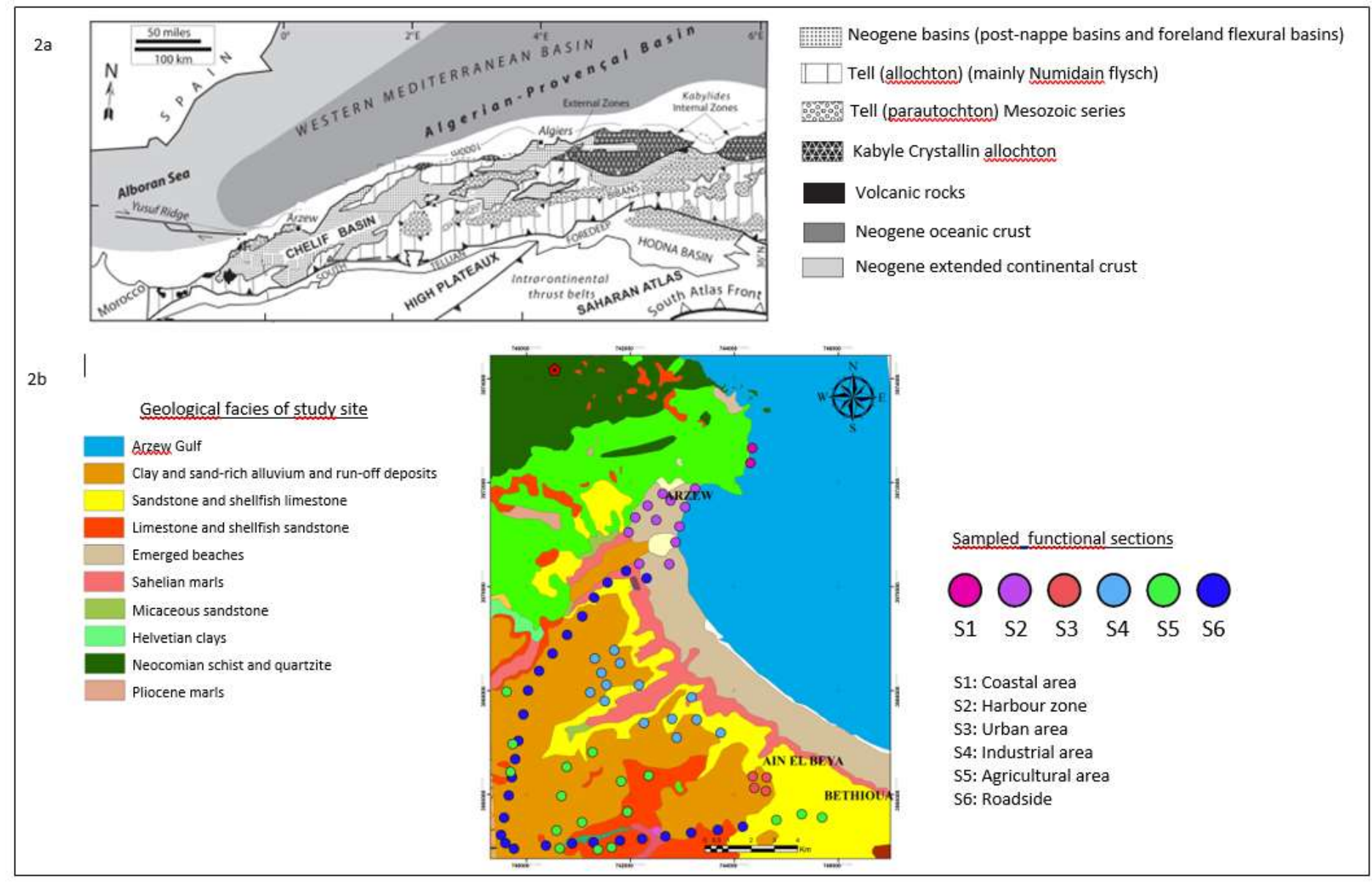

Figure 2: Geological and pedological characteristics of the study site 2a. Geological settings of the Chelif basin (from Arab et al., 2015); 2b. Pedological map issued from the general geology map designed by Fisher et Doumergue (1900) and locations of the sampling stations (S1 to S6)

The soils are mainly constituted of clays and sand-rich alluvium issue from run-off deposits, and of sandstone and limestone (Figure 2b; Ficheur et Doumergue 1908). Two main zones can be distinguished pedologically in the study sites: quartz-sand and humus-bearing soils, at 
the level of the dune coastal and sublittoral area, and alluvial soils with predominance of clay texture dominates. The climate is typical of a Meditteranean area, with mild temperatures throughout the year (data observed these last ten years: minimum: $15.4{ }^{\circ} \mathrm{C}$; maximum : 23.6 ${ }^{\circ} \mathrm{C}$; mean : $18.5^{\circ} \mathrm{C}$ ). Precipitations occur mainly between October and February, with average annual rainfall around $324 \mathrm{~mm}$.

\subsection{Sample collection}

A sum of 84 topsoil samples $(0-20 \mathrm{~cm})$ were collected from six functional sections around the petrochemical platform of Arzew, representing a triangular area $17 \mathrm{~km}$ wide by $12 \mathrm{~km}$ high. These six sections have been chosen to represent the main activities carried out by people working and/or living in this area. 9 samples were collected from coastal area (S1, beach zone), 13 collected from port area (S2, harbour zone with private recreational vessels and surrounded by several residential quarters), 4 collected from downtown Aïn El Bia (S3), 14 collected from the industrial area (S4, sample points scattered around the petrochemical platform), 17 collected from the agricultural area adjacent to the industrial site (S5), and 27 (S6) located in an area bound by the two-lane road N11 to the South, and by the two-lane road N13 to the West and North (Figure 2b). Another two unaffected soil samples (BG1 and BG2) were also collected from an area $15 \mathrm{~km}$ away from the petrochemical platform area (presumably unpolluted zones) and representing the two pedogeochimical soils of the study area, for background studies. All the sampling points were systematically distributed in the study area, recorded with a GPS and, collected in clean polythene bags to avoid contamination before analysis in the laboratory.

\subsection{Sample preparation and analysis}

Soil samples were sieved to $2 \mathrm{~mm}$ mesh, air-dried at room temperature and then ground (RETSCH zm 1000 with tungsten blades) to pass through a $0.2 \mathrm{~mm}$ titanium sieve before analyses. The acid digestion of the sampled soils $(0.5 \mathrm{~g})$ was carried out in a microwave mineralizer (Milestone Start D Microwave Labstation, Sorisole, Italy) using aqua regia (1/3 $\left.\mathrm{HNO}_{3}+2 / 3 \mathrm{HCl}\right)$. Suprapur grade $65 \%(\mathrm{~m} / \mathrm{m}) \mathrm{HNO}_{3}$ and $37 \%(\mathrm{~m} / \mathrm{m}) \mathrm{HCl}$ (Merck, Germany) were used for sample mineralization. This microwave digestion system was equipped with ten 100-mL tetrafluoromethoxy vessels and a ceramic vessel jacket. To protect the unit, the cavity and the door were plasmacoated with Polytetrafluoroethylene (PTFE). After digestion and cooling, the mineralized products were filtered with a $0.45-\mu \mathrm{m}$ mesh and diluted to a final volume of $25 \mathrm{~mL}$ with ultrapure water. The metal contents were determined 
by Inductively coupled Plasma-Atomic Emission Spectroscopy (ICP-AES, Jobin Yvon Horiba, Spectra 2000) for As, Cd, Co, Cr, Cu, Ni, Pb, and Zn. Monoelemental high-purity grade $1 \mathrm{~g} \mathrm{~L}^{-1}$ stock solutions of $\mathrm{As}, \mathrm{Cd}, \mathrm{Co}, \mathrm{Cr}, \mathrm{Cu}, \mathrm{Ni}, \mathrm{Pb}$, and $\mathrm{Zn}$ were purchased from Merck (Darmstadt, Germany). The purity of the plasma torch argon was greater than $99.99 \%$. The emission lines for the analysis by ICP-AES were (nm): As (193.696), Cd (214.438), Co (311.071), Cr (267.716), Cu (324.754), Ni (231.604), Pb (220.353), and Zn (213.856). Blanks were prepared for each lot of samples, and triplicate analyses were performed for each sample. Accuracy of the method and quality assurance-quality controls were verified by analyzing Trace Metals-Sandy Clay 1 certified reference materials (CRM 049-050 from RTC, USA) with accuracies within $100 \pm 10 \%$.

All laboratory glassware was soaked in a $10 \%(\mathrm{v} / \mathrm{v}) \mathrm{HNO}_{3}$ solution bath for $24 \mathrm{~h}$ and was rinsed with high-purity water, then dried under clean air conditions at ambient temperature. All reagents were of the highest commercially available purity grade. Deionized water (resistivity $18 \mathrm{M} \Omega \mathrm{cm}^{-1}$ ) that was obtained from a Milli-Q purification system (Millipore, Molsheim, France) was used to prepare all standard and sample solutions.

\subsection{Statistical analysis}

Relationships between MTE and their potential emission sources have been assessed by performing Pearson's correlation analysis and principal component analysis (PCA), by use of the commercially-available statistics software IBM SPSS version 24.0.0 for windows.

\subsection{Pollution indices}

The accumulation levels of individual MTE in soil samples were evaluated by use of the geoaccumulation index ( $\mathrm{I}_{\mathrm{geo}}$ ) and were calculated as presented in the Annex 1 in the supplementary material.

The potential ecological risk index (PERI) associated with MTE in soil samples has been calculated according Håkanson's methodology (1980).

The geoaccumulation index ( $\left.\mathrm{Igeo}_{\mathrm{g}}\right)$ was calculated as follows:

$$
I_{\text {geo }}=\log _{2}\left(C_{n} / 1.5 B_{n}\right)
$$

where $C_{n}$ is the concentration of the metal measured in soil and $B_{n}$ is the corresponding geochemical background value. These latter have been chosen in BG1 and BG2 according texture of soil considered. The constant 1.5 is introduced in this equation to minimize the variations due to lithogenic actions and effect of possible variations in the background values 
(Pathak et al, 2015). The $I_{g e o}$ for each metal is calculated and typically classified as follows: unpolluted $\left(\mathrm{I}_{\mathrm{geo}} \leq 0\right)$, unpolluted to moderately polluted $\left(0<\mathrm{I}_{\text {geo }} \leq 1\right)$, moderately polluted $(1<$ $\left.\mathrm{I}_{\text {geo }} \leq 2\right)$, moderately to heavily polluted $\left(2<\mathrm{I}_{\text {geo }} \leq 3\right)$, heavily polluted $(3<\mathrm{Igeo} \leq 4)$, heavily to extremely polluted $\left(4<\mathrm{I}_{\text {geo }} \leq 5\right)$, and extremely polluted $\left(\mathrm{I}_{\text {geo }}>5\right)$.

The PERI of each MTE was defined as being:

$$
\mathrm{E}_{\mathrm{r}}^{\mathrm{i}}=\mathrm{T}_{\mathrm{r}}^{\mathrm{i}} \times \mathrm{C}_{0}{ }^{\mathrm{i}} / \mathrm{C}_{\mathrm{n}}^{\mathrm{i}},
$$

where $\mathrm{T}_{\mathrm{r}}^{\mathrm{i}}$ is the toxic response factor of each metal $(\mathrm{As}=10, \mathrm{Ni}=6, \mathrm{~Pb}=\mathrm{Cu}=\mathrm{Co}=5, \mathrm{Cr}=$ $2, \mathrm{Zn}=1), \mathrm{C}_{0}{ }^{\mathrm{i}}$ is the concentration of each metal, and $\mathrm{C}_{\mathrm{n}}{ }^{\mathrm{i}}$ is the corresponding background value. The $\mathrm{E}_{\mathrm{r}}{ }^{\mathrm{i}}$ is classically classified following: low ecological risk $\left(\mathrm{E}_{\mathrm{r}}{ }^{\mathrm{i}} \leq 40\right)$, moderate ecological risk $\left(40<\mathrm{E}_{\mathrm{r}}^{\mathrm{i}} \leq 80\right)$, considerable ecological risk $\left(80<\mathrm{E}_{\mathrm{r}}{ }^{\mathrm{i}} \leq 160\right)$, high ecological risk $(160<$ $\left.\mathrm{E}_{\mathrm{r}}^{\mathrm{i}} \leq 320\right)$, and very high ecological risk $\left(\mathrm{E}_{\mathrm{r}}^{\mathrm{i}}>320\right)$.

\subsection{Non-carcinogenic risk assessment}

In this study, only children have been considered for the assessment of the probability of noncarcinogenic risks due to the presence of MTE in topsoils of Arzew. This public is exposed to MTE through the three main pathways that are direct ingestion (pica-behaviour not considered), inhalation of soil particles through nose and mouth, and dermal contact absorption. The human non-cancer risk effects from metals can be assessed using the hazard quotient (HQ), which is the ratio of the average daily dose (ADD) to the reference dose (RfD, $\mathrm{mg} \mathrm{kg}^{-1} \mathrm{day}^{-1}$ ) of a MTE for the same exposure pathway. These RfD used for the calculation of HQ are given in Table 1; they were taken from U.S. EPA Exposure Factors Handbook (2011), from the Risk Assessment Information System (RAIS) website.

Table 1: Reference dose (RfD) of MTE used for the calculation of the Average Daily Doses (ADD)

\begin{tabular}{llll} 
& $\begin{array}{l}\text { Ingestion RfD } \\
\left(\mathrm{mg} \mathrm{kg}^{-1} \mathrm{day}^{-1}\right)\end{array}$ & $\begin{array}{l}\text { Inhalation RfD } \\
\left(\mathrm{mg} \mathrm{kg}^{-1} \mathrm{day}^{-1}\right)\end{array}$ & $\begin{array}{l}\text { Dermal RfD } \\
\left(\mathrm{mg} \mathrm{kg}^{-1} \mathrm{day}^{-1}\right)\end{array}$ \\
\hline $\mathrm{As}$ & 0.0003 & 0.0000086 & 0.00012 \\
$\mathrm{Co}$ & 0.02 & 0.0000057 & 0.0000057 \\
$\mathrm{Cr}$ & 0.003 & 0.000029 & 0.00006 \\
$\mathrm{Cu}$ & 0.004 & 0.042 & 0.0012 \\
$\mathrm{Ni}$ & 0.02 & - & 0.0054 \\
$\mathrm{~Pb}$ & 0.0035 & 0.00352 & 0.0053 \\
$\mathrm{Zn}$ & 0.003 & 0.3 & 0.006 \\
\hline
\end{tabular}

The ADD is a dose averaged over a specified period. The general equation used for ADD is (U.S. EPA, 2014): 


$$
A D D(\text { soil ingestion })=\frac{C \text { soil } \times C F \times I R s o i l \times E F \times E T \times E D}{B W \times A T}(1)
$$

Where:

$\mathrm{ADD}_{\text {soil ing }}$ is the potential subchronic average daily dose of the contaminant from ingestion of contaminated soil $\left(\mathrm{mg} \mathrm{kg}^{-1}\right.$ day $\left.^{-1}\right)$;

$\mathrm{C}_{\text {soil }}$ is the concentration of the contaminant in the ingested soil $\left(\mathrm{mg} \mathrm{kg}^{-1}\right.$ soil);

$\mathrm{CF}$ is the conversion factor of $1.10^{-6} \mathrm{~kg} / \mathrm{mg}$;

$\mathrm{IR}_{\text {soil }}$ is the ingestion rate of soil $\left(\mathrm{mg} \mathrm{day}^{-1}\right)$. According to U.S. EPA recommendations (2011), the recommend central tendency ingestion rate of soil for children is $50 \mathrm{mg} \mathrm{day}^{-1}$;

$\mathrm{EF}$ is the exposure frequency (day year ${ }^{-1}$ ). In this calculation, this exposure frequency is set up at 350 days, assuming that children are away from home (from the source of contamination) for two weeks per year;

ET is the average time spent outside and playing at the contact of grounds. U.S. EPA (2011) estimates this duration at $202 \mathrm{~min}^{\mathrm{day}}{ }^{-1}$, by addition of the duration spent on playing on sand or gravel, on grass and on dirt. ET is thus equal to 0.14 (202 $\mathrm{min} / 24 \mathrm{~h})$;

ED is the exposure duration (year). Considering children as exposed populations, the duration has been set up at 18 years;

BW is the average body weight $(\mathrm{kg})$ on the considered period (18 years). According to the recommendations of U.S. EPA (2011), BW is equal to $41 \mathrm{~kg}$ (weight of children averaged on the 18 years' period);

AT is the averaging time (day), equivalent to the exposure timeframe. 350 days $\times 18$ years $=$ 6300 days;

When ADD is used to determine a dermal exposure, additional terms must be included (surface area, adherence factor or dermal permeability coefficient) and similarly when considering inhalation exposure (emission factor)

$A D D(A B S$ soil contact dermal $)=\frac{\text { Csoil } \times C F \times E F \times E D \times A B S \times \frac{S A}{B W} \times A F \text { soil }}{A T}(2)$

where EF is the exposure frequency (350 days per year), ED is the exposure duration (18 years), ABS is the absorption fraction (0.1, assuming that $10 \%$ of MTE in the soil contacting the skin is absorbed), SA/BW is the surface area of the skin that contacts the soil (only hands $0.057 \mathrm{~m}^{2}$-, arms $-0.176 \mathrm{~m}^{2}$ - and legs $-0.358 \mathrm{~m}^{2}$ - have been considered as being exposed to contaminated soils for the calculations) per $\mathrm{kg}$ of body weight $(41 \mathrm{~kg}), \mathrm{AF}_{\text {soil }}$ is the adherence 
factor for soil (mg cm${ }^{-2}$, depending on the body part considered; 0.110 .011 and $0.031 \mathrm{mg} \mathrm{cm}^{-}$ ${ }^{2}$, respectively for hands, arms and legs) and AT is the averaging time (6300 days).

$$
A D D(\text { soil particles inhalation })=\frac{C \operatorname{soil} \times I n h R \times E F \times E D}{P E F \times B W \times A T}(3)
$$

where InhR is the inhalation rate $\left(5 \mathrm{~m}^{3}\right.$ day $^{-1}$ for children $)$, and PEF is the particle emission factor $\left(1.36 \times 10^{9} \mathrm{~m}^{3} \mathrm{~kg}^{-1}\right)$.

The sum of the HQ (HQ ingestion $\left.+\mathrm{HQ}_{\text {dermal }}+\mathrm{HQ}_{\text {inhalation }}\right)$ represent the hazard index $(\mathrm{HI})$, that allow to estimate the potential non-carcinogenic effects following the value of $\mathrm{HQ}$. If $\mathrm{HI} \leq 1$, the exposed public is unlikeky to experience adverse health effects, whereas opposite effects are expected if $\mathrm{HI}>1$ (U.S. EPA 1989).

\section{Results and discussion}

\subsection{MTE concentrations}

Descriptive statistics of MTE concentrations (in $\mathrm{mg} \mathrm{kg}^{-1}$ ) in topsoils from the six sectors in Arzew and surroundings are summarized in Table 2, together with soil background values and French regulatory limits (AFNOR 1996). levels of Cd were very low with values below $0.01 \mathrm{mg} \cdot \mathrm{kg}^{-1}$ in all the samples and will not be discussed further. Globally, data obtained follow a normal distribution except for the road area (S6) where values of standardized skewness and standardized kurtosis are not within the range expected for data from a normal distribution $(-2,+2)$. This zone is the longest one among areas studied and the traffic is quite different between road N11 (mostly cars) and road N13 (mostly trucks). For the other zones and whatever metals considered, the coefficients of variation are relatively low and indicate a homogeneous contamination in all soil samples.

Total As concentrations of $95 \%$ of the samples were under $20.0 \mathrm{mg} \mathrm{kg}^{-1}$, the median value being $10 \mathrm{mg} \mathrm{kg}^{-1}$. A recent study carried out in 33 countries in Europe (Reimann et al. 2018) indicate that more of $95 \%$ samples soils presented a geochemical threshold value below 20 $\mathrm{mg} \mathrm{kg}^{-1}$. In China, geochemical reference value relative to As is $8.40 \mathrm{mg} \mathrm{kg}^{-1}$ (CNEMC 1990). In our sampling points considered as being unpolluted (BG1 and BG2), arsenic is highly below these guideline levels (around $4 \mathrm{mg} \mathrm{kg}^{-1}$ ). However, results of independent sample test $(\mathrm{p}<0.05)$ showed that concentrations of As is significantly higher in the S1 and S2 areas (mean: $15.63 \mathrm{mg} \mathrm{kg}^{-1}$; max: $48.06 \mathrm{mg} \mathrm{kg}^{-1}$ ) and exceed the French regulatory limit (37 $\mathrm{mg} \mathrm{kg}^{-1}$; AFNOR U44-041). Arsenic in soils may originated from not only natural sources 
Table 2 : Summary of MTE concentrations $\left(\mathrm{mg} \mathrm{kg}^{-1}\right)$ together with basic statistical parameters as spread among functionnal areas studied

\begin{tabular}{|c|c|c|c|c|c|c|c|c|}
\hline Sampling sites & Statistics & As & Co & $\mathrm{Cr}$ & $\mathrm{Cu}$ & $\mathrm{Ni}$ & $\mathrm{Pb}$ & $\mathrm{Zn}$ \\
\hline \multirow[t]{6}{*}{ Beach zone $(\mathrm{N}=9)$} & Min - Max & $4.52-14.12$ & $6.67-18.88$ & $35.85-77.93$ & 17.1- 48.21 & $20.82-43.77$ & $23.27-71.03$ & $54.78-113.84$ \\
\hline & Mean - Median & $8.04-6.2$ & $12.41-12.59$ & 58.22- 63.39 & $25.36-21.23$ & 32.23- 34.53 & $43.11-40.48$ & $84.57-84.64$ \\
\hline & SD & 3.62 & 4.37 & 16.19 & 9.96 & 8.45 & 17.11 & 17.41 \\
\hline & CV\% & 44.97 & 35.21 & 27.81 & 39.28 & 26.23 & 39.69 & 20.59 \\
\hline & Skewness & 0.91 & 0.24 & -0.41 & 2.27 & -0.26 & 0.59 & -0.05 \\
\hline & Kurtosis & -0.34 & -0.66 & -1.00 & 1.99 & -0.9 & -0.59 & 0.53 \\
\hline \multirow{6}{*}{ Harbour zone $(\mathrm{N}=13)$} & Min - Max & $4.99-48.06$ & $5.31-18.86$ & $33.63-89.31$ & $17.1-34.52$ & $16.64-51.84$ & $23.27-83.04$ & $54.78-112.34$ \\
\hline & Mean - Median & $15.64-8.6$ & $11.89-12.19$ & $59.96-63.39$ & $23.18-22.55$ & $33.41-34.53$ & $46.68-43.47$ & $82.06-83.05$ \\
\hline & SD & 14.01 & 4.92 & 17.59 & 4.99 & 9.99 & 18.16 & 14.71 \\
\hline & CV\% & 89.62 & 39.06 & 29.34 & 21.56 & 29.91 & 38.91 & 17.92 \\
\hline & Skewness & 2.21 & 0.61 & -0.10 & 1.28 & 0.03 & 0.96 & 0.30 \\
\hline & Kurtosis & 0.81 & -0.25 & -0.64 & 0.77 & -0.16 & -0.11 & 0.74 \\
\hline \multirow[t]{6}{*}{ Downtown $(\mathrm{N}=4)$} & Min - Max & $1.58-11.3$ & $4.67-14.0$ & $35.67-77.93$ & $12.33-19.91$ & $15.62-24.88$ & $15.12-35.16$ & $40.8-75.3$ \\
\hline & Mean - Median & $6.66-7.12$ & $9.95-10.58$ & $50.38-43.96$ & $16.59-17.06$ & $20.56-20.88$ & $27.06-30.9$ & $55.46-50.3$ \\
\hline & SD & 4.87 & 4.09 & 18.77 & 3.38 & 3.83 & 10.55 & 17.82 \\
\hline & CV\% & 73.13 & 41.10 & 37.27 & 20.39 & 18.62 & 39.01 & 32.13 \\
\hline & Skewness & -0.29 & -0.56 & 1.41 & -0.47 & -0.38 & -1.00 & 0.84 \\
\hline & Kurtosis & - & -0.30 & 1.34 & -0.65 & 0.46 & - & - \\
\hline \multirow[t]{6}{*}{ Industrial zone $(\mathrm{N}=14)$} & Min - Max & $4.92-19.4$ & $3.77-12.98$ & $11.33-193.36$ & $10.31-40.53$ & $6.38-50.74$ & $30.15-56.98$ & $70.41-285.7$ \\
\hline & Mean - Median & $13.05-14.545$ & $7.38-6.08$ & $51.17-45.36$ & $19.82-15.4$ & $24.00-22.74$ & $45.56-45.72$ & $147.36-137.56$ \\
\hline & SD & 4.14 & 3.36 & 49.32 & 10.01 & 15.89 & 8.66 & 63.4 \\
\hline & CV\% & 31.73 & 45.59 & 88.46 & 50.55 & 66.21 & 19.01 & 43.02 \\
\hline & Skewness & -0.67 & 0.86 & 2.64 & 1.58 & 0.57 & -0.38 & 1.30 \\
\hline & Kurtosis & -0.49 & -1.19 & 3.00 & -0.17 & -1.06 & -0.87 & 0.13 \\
\hline \multirow[t]{6}{*}{ Agricultural zone ( $N=17$ ) } & Min - Max & $4.92-19.4$ & $3.9-12.98$ & $12.09-93.2$ & $10.31-63.31$ & $8.41-46.99$ & $30.15-83.64$ & $41.23-99.27$ \\
\hline & Mean - Median & $11.57-10.41$ & $8.47-8.72$ & $50.16-54.98$ & $27.14-20.77$ & $24.41-25.59$ & $48.69-46.24$ & $73.75-76.47$ \\
\hline & SD & 3.79 & 3.13 & 23.92 & 16.91 & 11.78 & 14.77 & 16.07 \\
\hline & CV\% & 32.83 & 37.02 & 47.68 & 62.31 & 48.26 & 30.34 & 21.79 \\
\hline & Skewness & 0.24 & -0.18 & -0.31 & 2.06 & 0.31 & 1.84 & -0.54 \\
\hline & Kurtosis & -0.24 & -1.22 & -0.61 & 0.55 & -0.63 & 0.66 & -0.40 \\
\hline \multirow{6}{*}{ Road zone ( $N=27$ ) } & & & & & & & & \\
\hline & $\begin{array}{l}\text { Min - Max } \\
\text { Mean - Median }\end{array}$ & $\begin{array}{l}4.67-16.41 \\
10.85-10.48\end{array}$ & \begin{tabular}{|l|}
$3.43-14.84$ \\
$10.81-11.14$
\end{tabular} & $\begin{array}{l}14.42-84.2 \\
55.39-60.66\end{array}$ & $\begin{array}{l}11.28-223.7 \\
31.95-21.53\end{array}$ & \begin{tabular}{|l|l}
$5.06-42.13$ \\
$27.20-30.62$
\end{tabular} & $\begin{array}{l}45.6-220.5 \\
98.4-77.00\end{array}$ & $\begin{array}{l}48.5-168.5 \\
89.29-83.34\end{array}$ \\
\hline & SD & 3.34 & 2.87 & 21.73 & 41.30 & 10.67 & 51.85 & 31.11 \\
\hline & CV\% & 30.76 & 26.59 & 39.23 & 129.28 & 39.25 & 52.70 & 34.85 \\
\hline & Skewness & -0.38 & -2.34 & -1.33 & 8.94 & -1.60 & 2.86 & 2.38 \\
\hline & Kurtosis & -0.63 & 0.76 & -1.05 & 20.44 & -0.67 & 0.86 & 1.06 \\
\hline \multicolumn{9}{|l|}{ Soil background values } \\
\hline BG1 (quartz-sand and humus-bearing soil) & & 3.58 & 3.44 & 21.64 & 17.1 & 12.63 & 24.56 & 42.95 \\
\hline BG2 (alluvial soil) & & 4.52 & 3.77 & 11.33 & 10.73 & 7.19 & 13.27 & 40.43 \\
\hline PNEC & & 0.7 & 10.9 & $3.2(\mathrm{Cr} I I I)$ & 65 & 29.9 & 109 & 106.8 \\
\hline Regulatory limit & & 37 & 30 & 150 & 100 & 50 & 100 & 300 \\
\hline PNEC : Predicted No E & & & & & & & & \\
\hline Regulatory limit : French regulatory limit & $R, 1996)$ & & & & & & & \\
\hline
\end{tabular}


such as erosion or weathering of rocks, but also from anthropogenic activities including industrial emissions, application of pesticides, sewage irrigation, and atmospheric deposition (Zhou et al. 2018). At the opposite, levels of As are comparatively relatively low in S5 (agricultural area), suggesting that As-rich fertilizers or pesticides have not been intensively used up to now in this area (Figure 3). Because of location of higher contaminated sampling points in S2, and because this area is under prevailing southerly winds, As is supposed to come from the industrial area (S5).
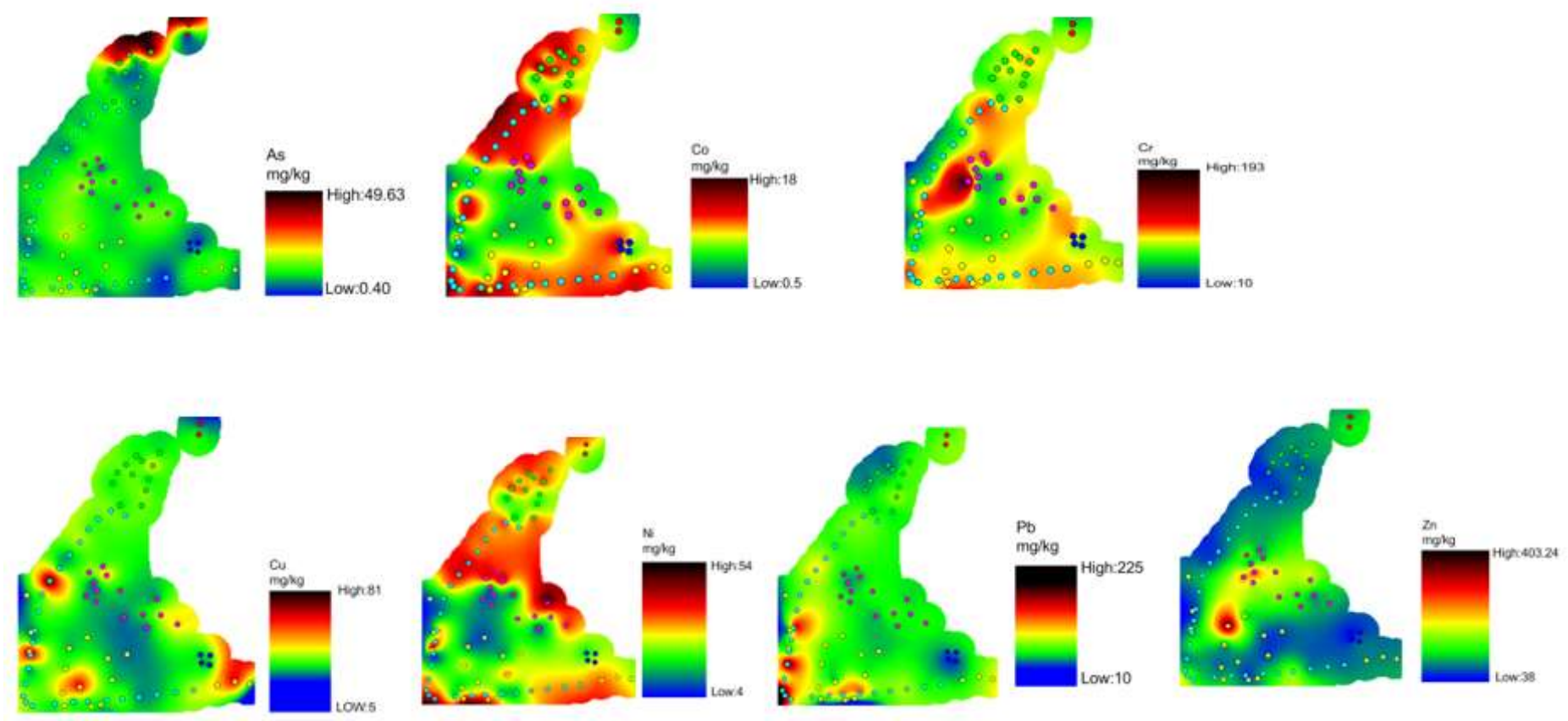

Figure 3: Spatial distribution of MTE in Arzew (3551'13' N; 0¹8'52" W)

Concentrations of Co observed in the soils of Arzew and its surroundings (Table 1) are in agreement with pedogeochemical background values. $100 \%$ of the samples are below the French regulatory limit concerning Co $\left(30 \mathrm{mg} \mathrm{kg}^{-1}\right)$. Mean Co levels are $10.13 \mathrm{mg} \mathrm{kg}^{-1}$ (min: 3.43; max: 21.83) and relatively close to the BG1 and BG2 levels (Table 1), with at least an order of magnitude three higher than these background levels. The mean levels of Co were similar between S1, S2, S3 and S6 (around $12 \mathrm{mg} \cdot \mathrm{kg}^{-1}$ ), and S3 and S4 (around $7 \mathrm{mg} . \mathrm{kg}^{-1}$ ). Dissemination of cobalt in the environment is mainly caused by mining activities, smelting and industrial processing and incineration of combustible municipal solid waste (Leyssens et al. 2017). From these results, it can be suggested that the petrochemical platform does not emit cobalt in the atmosphere (lowest level of Co in S4), or a high dispersion due to the wind or a low retention of $\mathrm{Co}$ in the topsoil.

Total $\mathrm{Cr}$ concentrations have a median of $60 \mathrm{mg} \mathrm{kg}^{-1}$ with a high range (14.42 - $\left.193 \mathrm{mg} \mathrm{kg}^{-1}\right)$. Only one sample exceed the French regulation limit $\left(150 \mathrm{mg} \mathrm{kg}^{-1}\right)$ and is in the industrial area (S4, Table 1 and Figure 3). However, the whole sampling sites (except the agricultural area) 
present a relatively high level of $\mathrm{Cr}$, with $90 \%$ of samples having $\mathrm{Cr}$ at more than $80 \mathrm{mg} \mathrm{kg}^{-1}$, representing levels eight times higher than BG2. These levels exceed also the (eco)toxicological PNEC values derived by the European REACH regulation (Table 1).

Origin of $\mathrm{Cr}$ input into the soils may come from phosphate fertilizers and metallurgical industries (Maas et al. 2010). The diffuse Cr concentrations measured in the soils of our sampling sites suggest that agricultural activities may use Cr-containing materials (but statistically this area is not contaminated by $\mathrm{Cr}$ ), and more probably that chromium found in the whole sampling sites may be originated from the industrial platform of Arzew. However, presence of $\mathrm{Cr}$ due to the road traffic cannot be excluded; indeed, its presence has already been associated with the bulk matrix from road dust, and yellow road paint and road pavement are typically sourcing of Cr (Thorpe and Harrison 2008).

Total $\mathrm{Cu}$ concentrations have a mean of $25.91 \mathrm{mg} \mathrm{kg}^{-1}$ and a median of $20.77 \mathrm{mg} \mathrm{kg}^{-1}$. Concentrations are globally homogeneous within the study area, although there are two functional areas that differ significantly, namely S5 in its southeastern portion and S6 in its western portion. In these latter portions, $\mathrm{Cu}$ levels are significantly higher than in the other areas, with levels higher than $60 \mathrm{mg} \mathrm{kg}^{-1}$ (max: 63.31 in S5; max: 223.7 in S6) (Table 1 and Figure 3). In S5, the presence of copper is associated to the use as a post-harvest fungicides of Bordeaux mixture (made of lime and copper sulphate) on orange trees. In S6, the presence is associated to the vicinity of the road traffic. $\mathrm{Cu}$ is known to be abundant in brake lining materials, to be used in road pavement applications and could thus be found in particulate matter and dust in the urban environment (Men et al., 2018).

Ni presents the same pattern of geographical distribution as Co, but with higher levels (Figure $\mathrm{S} 1)$. Total Ni concentrations have a median of $28.54 \mathrm{mg} \mathrm{kg}^{-1}$ and a mean of $26.94 \mathrm{mg} \mathrm{kg}^{-1}$ $(\min =5.06 ; \max =51.84) .99 \%$ of the samples are below the French regulatory limit $(50 \mathrm{mg}$ $\left.\mathrm{kg}^{-1}\right)$ and $50 \%$ are below the PNEC value $\left(65 \mathrm{mg} \mathrm{kg}^{-1}\right)$. The highest concentrations are found in the coastal area (S1), in the harbour one (S2) and along the road zone (S6), with some sampling points having $\mathrm{Ni}$ at more than $50 \mathrm{mg} \mathrm{kg}^{-1}$. Ni is widely used in various industrial sectors such as refining industry, textile and painting industry, foundries and metal processing industries (Aden et al. 2017).

Total $\mathrm{Pb}$ concentrations have a median of $52.11 \mathrm{mg} \mathrm{kg}^{-1}$ with a high range (13.27-220.5 mg $\mathrm{kg}^{-1}$ ) (Table 1). Average concentrations are $63 \mathrm{mg} \mathrm{kg}^{-1}$ in the study area but the highest levels are found in S6, area representing the road zone, with $50 \%$ of samples $(\mathrm{N}=27)$ exceeding 100 $\mathrm{mg} \mathrm{kg} \mathrm{kg}^{-1}$, which is the French regulatory limit for this MTE. Such an increase in $\mathrm{Pb}$ concentrations in areas with dense traffic has been observed in other cities, even with the 
sharp increase of unleaded fuel utilization in European countries because of the high stability of lead in soils (Turner and Lewis 2018). Moreover, in Algeria 89\% of the gasoline consumption is still leaded (Maas et al. 2010). Therefore, the locations of $\mathrm{Pb}$, together with absence of lead in the surroundings of the industrial platform, let us think that road traffic is the most likely sources of $\mathrm{Pb}$ in these soils.

None of the measured $\mathrm{Zn}$ concentrations exceed $300 \mathrm{mg} \mathrm{kg}^{-1}$, which is the PNEC for value for this metal (Table 2). Their median and mean concentrations are 83.34 and $93.27 \mathrm{mg} \mathrm{kg}^{-1}$, respectively. The highest concentrations are found in the industrial area (S4) and along the road (S6), with $80 \%$ samples and $30 \%$ samples being at levels above 100 mg. $\mathrm{kg}^{-1}$, respectively. $\mathrm{Zn}$ present in roadside soils is known to be issued from tire abrasion, lubricating oil, vehicular exhaust and breakpad wears (Morse et al. 2016) and atmospheric deposits of Zn to topsoils are mainly associated to municipal waste incinerators coal combustion residues, spillage of petrochemicals, mining and smelting industries and wildfires (Mousavi et al. 2018).

\subsection{Correlation between metals}

Statistical correlation analysis may provide an efficient method to understand the influencing factors and the sources of chemical contaminants. High correlations between MTE in soil may reflect that the accumulated concentrations of these metals come from similar emission sources. The results of the Pearson's correlation coefficient and their significance levels $(p<$ 0.01) are presented in Table 3. Co demonstrates a significant positive relationship with $\mathrm{Cr}$ (0.474) and $\mathrm{Ni}(0.580)$, as well as Cr with $\mathrm{Ni}(0.417)$. Concomitant presence of Co and Ni had been previously observed (Table 1 and Figure 3) in discussions above (paragraph 3.2) and their presence had been mainly associated with natural background levels. For other metals, very weak correlations are obtained, suggesting that MTE come from various sources.

Table 3: Correlations between MTE concentrations

\begin{tabular}{llllllll}
\hline & As & Co & $\mathrm{Cr}$ & $\mathrm{Cu}$ & $\mathrm{Ni}$ & $\mathrm{Pb}$ & $\mathrm{Zn}$ \\
\hline As & 1.000 & & & & & & \\
$\mathrm{Co}$ & -0.106 & 1.000 & & & & & \\
$\mathrm{Cr}$ & -0.008 & $\mathbf{0 , 4 7 4 * *}$ & 1.000 & & & & \\
$\mathrm{Cu}$ & 0.018 & 0.095 & 0.113 & 1.000 & & & \\
$\mathrm{Ni}$ & -0.072 & $\mathbf{0 . 5 8 0 * *}$ & $\mathbf{0 . 4 1 7 * *}$ & -0.081 & 1.000 & & \\
$\mathrm{~Pb}$ & -0.048 & 0.080 & 0.016 & -0.013 & -0.054 & 1.000 & \\
$\mathrm{Zn}$ & 0.097 & -0.179 & -0.005 & -0.127 & $-0.242^{*}$ & 0.092 & 1.000 \\
\hline
\end{tabular}

$* \mathrm{p}<0.05$

$* * p<0.01$ 


\subsection{Principal component analysis}

PCA can be conducted to identify the potential sources of contamination (Tang et al. 2017), which may be responsible of the spatial distribution patterns of MTE. The Kaiser-MeyerOlkin Index was calculated at 0.605 and results of the Bartlett's sphericity test were significant at $\mathrm{p}<0.01$, confirming that MTE concentrations were suitable for PCA. According to the results of the initial eigenvalues (higher than 1.00), four principal components are considered and explain $75.551 \%$ of the total variance (Table 4)

\begin{tabular}{|c|c|c|c|c|c|c|c|c|c|}
\hline \multirow{2}{*}{ Component } & \multicolumn{3}{|c|}{ Initial eigenvalues } & \multicolumn{3}{|c|}{ Extraction sums of squared loadings } & \multicolumn{3}{|c|}{ Rotation sums of squared loadings } \\
\hline & Total & $\%$ of variance & Cumulative $\%$ & Total & $\%$ of variance & Cumulative $\%$ & Total & $\%$ of variance & Cumulative $\%$ \\
\hline 1 & 2.070 & 29.578 & 29.578 & 2.070 & 29.578 & 29.578 & 2.000 & 28.565 & 28.565 \\
\hline 2 & 1.127 & 16.100 & 45.678 & 1.127 & 16.100 & 45.678 & 1.113 & 15.901 & 44.467 \\
\hline 3 & 1.057 & 15.096 & 60.774 & 1.057 & 15.096 & 60.774 & 1.099 & 15.701 & 60.168 \\
\hline 4 & 1.034 & 14.777 & 75.551 & 1.034 & 14.777 & 75.551 & 1.077 & 15.383 & 75.551 \\
\hline 5 & 0.834 & 11.912 & 87.463 & & & & & & \\
\hline 6 & 0.505 & 7.210 & 94.673 & & & & & & \\
\hline 7 & 0.373 & 5.327 & 100.000 & & & & & & \\
\hline
\end{tabular}

Table 4: Total variance of explained and component matrices

The results of the matrix of the PCA together with its loading plot are shown in Figure 4.

\begin{tabular}{clllllll}
\hline Component & $\mathrm{As}$ & $\mathrm{Co}$ & $\mathrm{Cr}$ & $\mathrm{Cu}$ & $\mathrm{Ni}$ & $\mathrm{Pb}$ & $\mathrm{Zn}$ \\
\hline 1 & -0.175 & $\mathbf{0 . 8 4 8}$ & $\mathbf{0 . 7 1 0}$ & 0.128 & $\mathbf{0 . 8 1 9}$ & 0.008 & -0.360 \\
2 & 0.093 & 0.123 & 0.249 & -0.449 & 0.044 & $\mathbf{0 . 6 0 2}$ & $\mathbf{0 . 6 8 9}$ \\
3 & $\mathbf{0 . 7 5 8}$ & 0.025 & 0.315 & 0.540 & -0.110 & -0.128 & 0.250 \\
4 & -0.366 & 0.059 & -0.005 & $\mathbf{0 . 6 4 4}$ & -0.276 & $\mathbf{0 . 6 3 3}$ & -0.076 \\
\hline
\end{tabular}

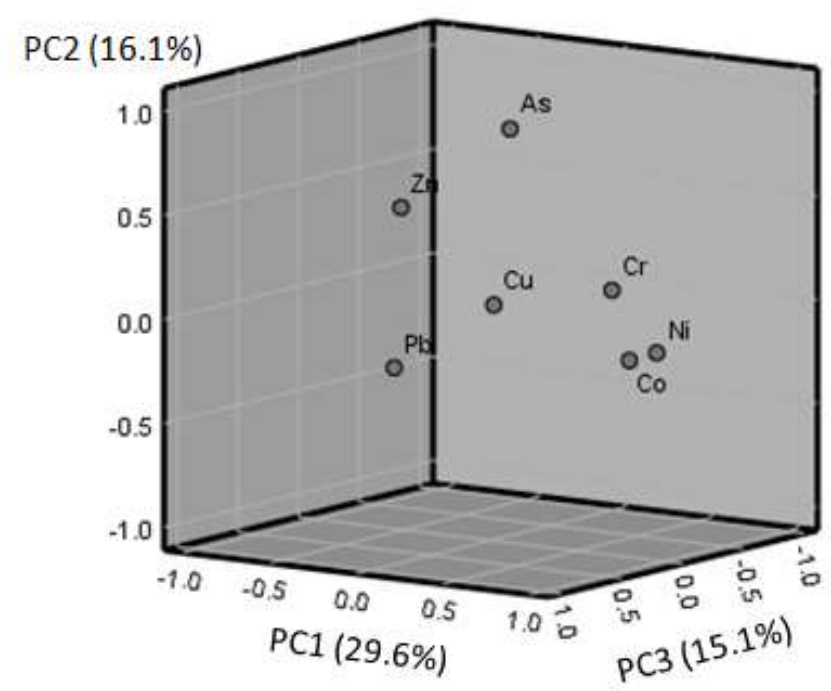

Figure 4: Matrix of the principal component analysis loadings of MTE and its corresponding loading plots 
The first principal component (PC1) explains $29.6 \%$ of the total variance. It includes significant loading values for $\mathrm{Co}(0.848), \mathrm{Cr}(0.710)$ and $\mathrm{Ni}(0.819)$. Concentrations of these three metals in most of our soil samples are present at levels three times higher than their background levels. These three metals are also positively correlated with each other (Table 2), suggesting similarities in their sources. These three MTE are also mostly located in zones S1, S2 and S6 (in its North western portion) and their highest concentrations are found in S4 (industrial area), suggesting a main emission source from the industrial platform and a dissemination of metallic particles from South to North in the study area.

In the loading plot (Figure 4), $\mathrm{Pb}$ and $\mathrm{Zn}$ form a group, with similar loading for PC2 (loading values of 0.602 and 0.689 , respectively), explaining $16.1 \%$ of the total variance. Their respective highest concentrations are found in S4, representing the road zone, suggesting thus a similar origin issued from the road traffic.

PC3 accounts for $15.1 \%$ of the total variance and is dominated mainly by As $(0.758)$, with a low contribution of $\mathrm{Cu}(0.540), \mathrm{Cu}$ being mainly associated to PC4 (0.644). Mean concentrations of As are found between 6.2 and $14.54 \mathrm{mg} \mathrm{kg}^{-1}$, regardless the area studied. However, we observe that the highest mean is found in the industrial area (S4), whereas the highest concentration is present in the harbour zone (S2), suggesting -as for $\mathrm{Co}, \mathrm{Cr}$ and $\mathrm{Ni}$ - an emission source from the industrial platform towards the harbour zone.

$\mathrm{Cu}$ and $\mathrm{Pb}$ are linked together in PC4 (14.8\%) with respective loadings value of 0.644 and 0.633. As seen before, these two metals are also distributed in $\mathrm{PC} 2(\mathrm{~Pb})$ and in $\mathrm{PC} 3(\mathrm{Cu})$. This suggest that these metals are controlled by more than one factor and they originate from mixed sources, such as industrial activities and road traffic.

\subsection{Pollution indices}

Figure 6 presents the box plots of the $I_{g e o}$ in soil samples as a function of the functional areas under study. In all the areas studied, the mean Igeo are found between 0 and 1.00 for As, Co, $\mathrm{Cu}$ and $\mathrm{Zn}$, indicating a low pollution level due to these MTE. The average Igeo values for $\mathrm{Cr}$, $\mathrm{Ni}$ and $\mathrm{Pb}$ is found between 1.00 and 1.50 , indicating a moderate pollution with these MTE. 


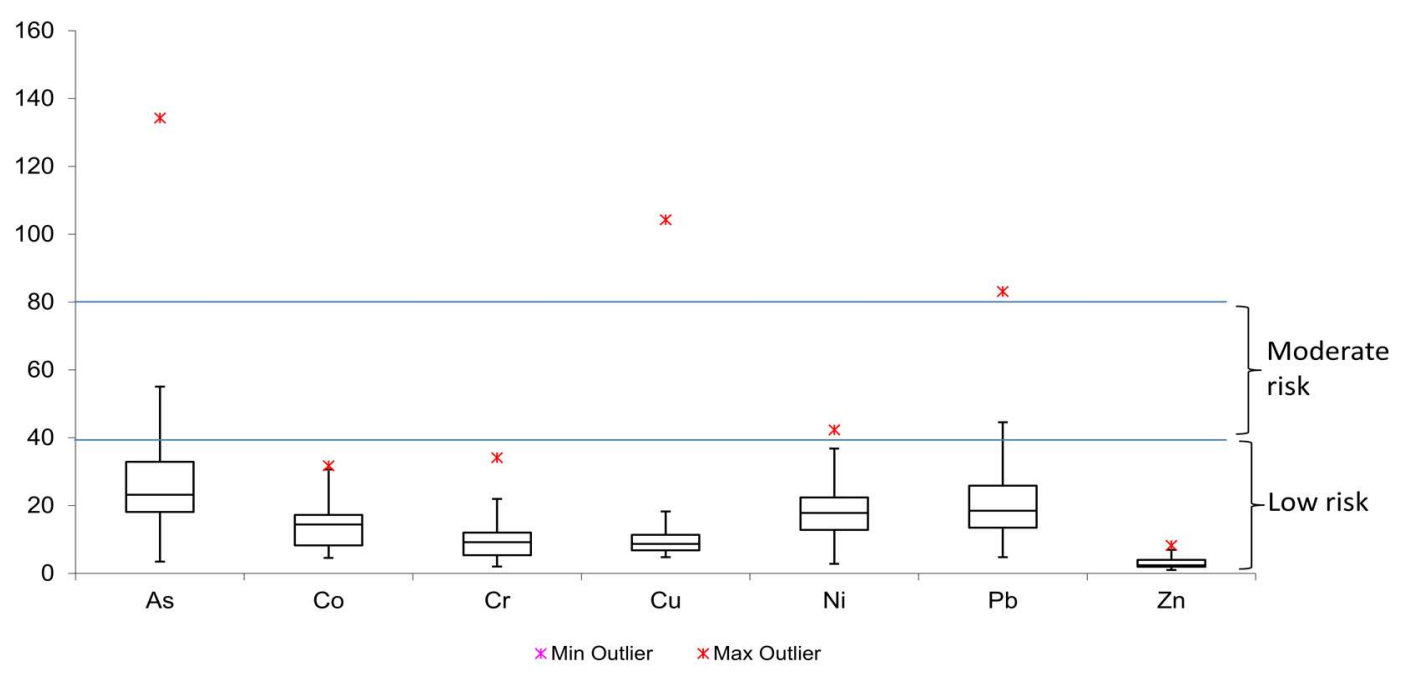

Figure 5: Monomial potential ecological risk (Eri) for MTE in topsoils of Arzew

The ends of the whisker are set at $1.5 \times$ IQR (interquartile range) above the third quartile and $1.5 \times$ IQR below the first quartile. When the maximum values are outside this range, then they are shown as outliers 

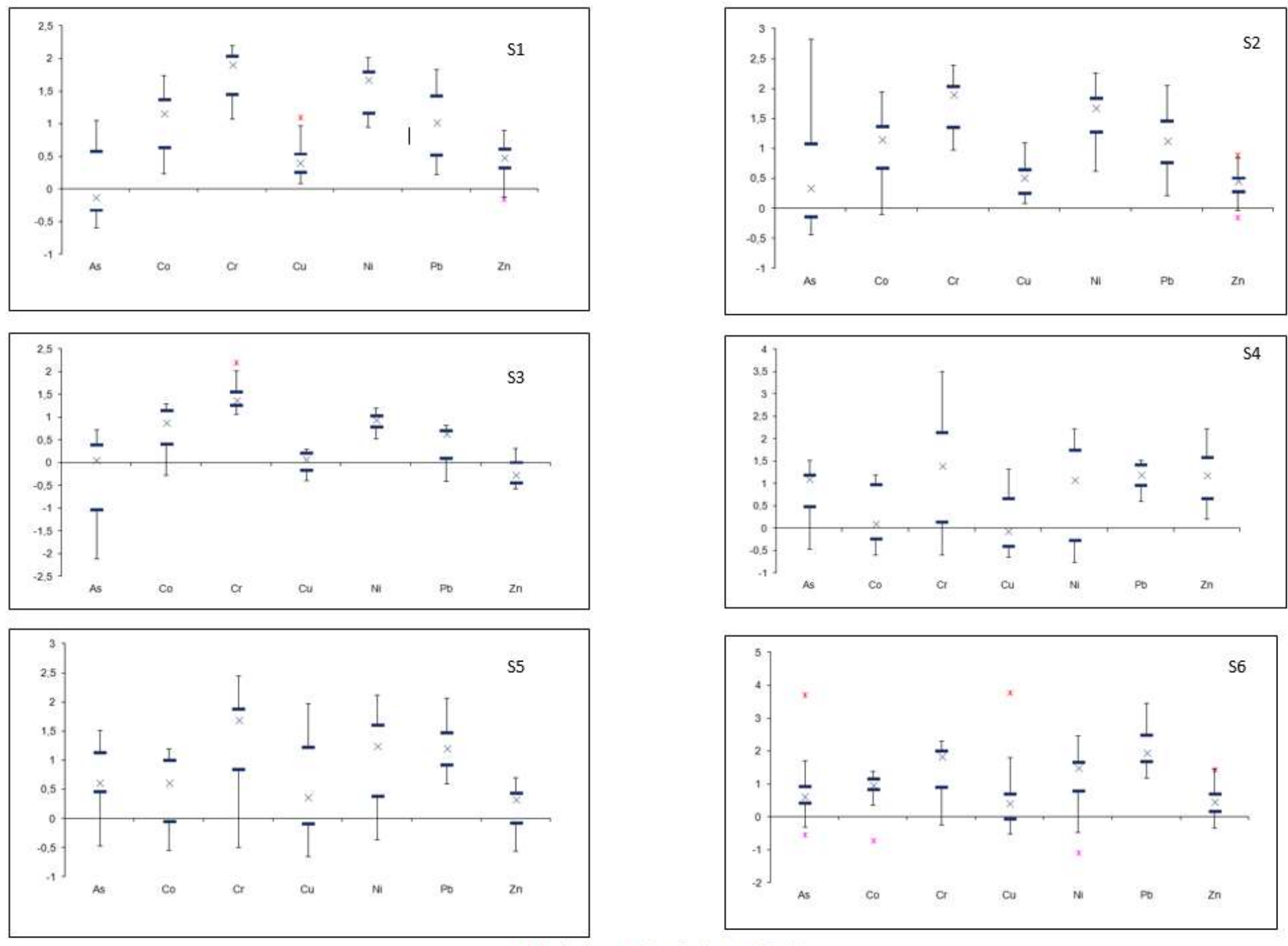

xMin Outlier $\quad *$ Max Outlier $\times$ Median

Figure 6 : Box plots of the Igeo for $\mathrm{As}, \mathrm{Cr}, \mathrm{Cu}, \mathrm{Co}, \mathrm{Pb}$, and $\mathrm{Zn}$ in soil samples as a function of the functional areas under study 
Also noteworthy is the fact that Igeo value for $\mathrm{Cr}$ exceed 1.0 in $71.6 \%$ of the whole samples, and even 2.00 in $45 \%$ of the samples, with $63 \%$ exceeding 2.00 in samples issued from S6, $46 \%$ from $\mathrm{S} 4$, and $37.5 \%$ from $\mathrm{S} 1$. The same observation can be made with respect to $\mathrm{Pb}$ with the finding of the 1.00 value is exceeded in $100 \%$ of the samples issued from S6, and where $\mathrm{Igeo}_{\text {ge }}$ are beyond 3.00 in $14,8 \%$ of the samples.

In all the soil samples, the $\mathrm{E}_{\mathrm{r}}^{\mathrm{i}}$ values for $\mathrm{As}, \mathrm{Co}, \mathrm{Cr}, \mathrm{Cu}, \mathrm{Ni}, \mathrm{Pb}$ and $\mathrm{Zn}$ are less than 40 (Figure 5), except in S6 (road zone), where 7 samples (26\%) exceed the value of 40 whose 2 exceed the $E_{r}{ }^{i}$ value of 80 . The $E_{r}{ }^{i}$ value of 40 for As is also exceeded in four samples (2 samples in $\mathrm{S} 2$ with $\mathrm{E}_{\mathrm{r}}^{\mathrm{i}}$ value of 95, 1 sample in $\mathrm{S} 4$ and 1 sample in $\mathrm{S} 5$ with an $\mathrm{E}_{\mathrm{r}}^{\mathrm{i}}$ value of 42). Globally, a low potential ecological risk is thus observed in the studied area but the impregnation with $\mathrm{Pb}$ in the road zone is significant, and a large zone is contaminated in such levels of $\mathrm{Pb}$ that this zone may be considered as presenting a moderate to considerable ecological risk. A special attention must also be devoted to the As monitoring in S5, where market gardening activities are carried out (artichokes, potatoes, spinach, peas).

\subsection{Potential health risks}

The non-carcinogenic health risks to children living in the vicinity of the study area have been calculated by use of the HQ values for the different exposure pathways of MTE found in topsoils. The HQ values obtained are presented in Table $\mathbf{5}$ and show a risk in the following order: ingestion $>$ dermal $>$ inhalation. Individually, none of the metals present a HQ superior to 1.0, except $\mathrm{Co}$ in the coastal (S1) but above all, $\mathrm{Cr}$ in all functional areas (except in $\mathrm{S} 1$ ). Speciation of chromium has not been conducted during the present study, and it is not possible to know what form of chromium is present $\left(\mathrm{Cr}^{+3}\right.$, non-toxic, or $\mathrm{Cr}^{+6}$, highly toxic). However, the results found are a very concerning issue for children living in Arzew as $\mathrm{Cr}^{+6}$ is known to induce cancer following oral exposure and chronic low-level skin exposure to $\mathrm{Cr}^{+3} \mathrm{or}^{+16}$ can cause permanent sensitisation that leads to allergic contact dermatitis and both $\mathrm{Cr}^{+3}$ or $\mathrm{Cr}^{+6}$ are known to be respiratory and mucous irritants (Broadway et al. 2010). Moreover, when considering the combined HI values from the seven metals, high potential non-carcinogenic risk to the local children is observed, with all values exceeding 2.0 and reaching up to 3.7 in the downtown and along the road zone.

Even these results remain uncertain because of the nature of the risk assessment (exposure parameters, duration of exposure, non-inclusion of speciation and bioavailability of metals, but also the absence of determination of MTE in fruits and vegetables grown and consumed in Arzew), and analytical results issued from only one sampling campaign, the health risks posed 
by the multi-contamination of Arzew soils, appear to seek to force local authorities, at a minimum, to conduct a more extensive study and prevent people of potential risks at playing, working and, growing vegetables in these polluted areas, and at best, to immediate remediation of the contaminated topsoils.

Table 5: Ingestion. dermal and inhalation Hazard Quotients and resulting Hazard Index

\begin{tabular}{|c|c|c|c|c|c|c|c|c|c|}
\hline Sampling sites & & As & $\mathrm{Co}$ & $\mathrm{Cr}$ & $\mathrm{Cu}$ & $\mathrm{Ni}$ & $\mathrm{Pb}$ & $\mathrm{Zn}$ & $\mathrm{HI}$ \\
\hline \multirow[t]{4}{*}{ Beach zone } & $H Q_{\text {ingestion }}$ & 0.16000 & 0.00370 & 0.11586 & 0.00378 & 0.00962 & 0.07353 & 0.16829 & \\
\hline & $\mathrm{HQ}_{\text {dermal }}$ & 0.03142 & 1.02110 & 0.45509 & 0.00991 & 0.00280 & 0.00381 & 0.00661 & \\
\hline & $\mathrm{HQ}_{\text {inhalation }}$ & 0.00008 & 0.00020 & 0.00018 & 0.00000 & & 0.00000 & 0.00000 & \\
\hline & $\mathrm{HI}$ & 0.19150 & 1.02500 & 0.57112 & 0.01370 & 0.01242 & 0.07735 & 0.17490 & 2.06600 \\
\hline \multirow[t]{4}{*}{ Harbour zone } & $\mathrm{HQ}_{\text {ingestion }}$ & 0.31124 & 0.00355 & 1.19320 & 0.46128 & 0.00997 & 0.07962 & 0.16330 & \\
\hline & $\mathrm{HQ}_{\text {dermal }}$ & 0.06113 & 0.97832 & 0.46869 & 0.00906 & 0.00290 & 0.00413 & 0.00641 & \\
\hline & $\mathrm{HQ}_{\text {inhalation }}$ & 0.00016 & 0.00019 & 0.00019 & 0.00000 & & 0.00000 & 0.00000 & \\
\hline & $\mathrm{HI}$ & 0.37253 & 0.98205 & 1.66208 & 0.47034 & 0.01287 & 0.08375 & 0.16971 & 3.75334 \\
\hline \multirow[t]{4}{*}{ Downtown } & $H Q_{\text {ingestion }}$ & 0.13253 & 0.00297 & 1.00256 & 0.33014 & 0.00614 & 0.04616 & 0.11037 & \\
\hline & $\mathrm{HQ}_{\text {dermal }}$ & 0.02603 & 0.81869 & 0.39380 & 0.00648 & 0.00179 & 0.00239 & 0.00434 & \\
\hline & $\mathrm{HQ}_{\text {inhalation }}$ & 0.00007 & 0.00016 & 0.00016 & 0.00000 & & 0.00000 & 0.00000 & \\
\hline & $\mathrm{HI}$ & 0.15863 & 0.82182 & 1.39652 & 0.33662 & 0.00792 & 0.04855 & 0.11470 & 2.88477 \\
\hline \multirow[t]{4}{*}{ Industrial zone } & $H Q_{\text {ingestion }}$ & 0.25970 & 0.00220 & 1.01828 & 0.39442 & 0.00716 & 0.07771 & 0.29325 & \\
\hline & $\mathrm{HQ}_{\text {dermal }}$ & 0.05100 & 0.60723 & 0.39998 & 0.00775 & 0.00208 & 0.00403 & 0.01152 & \\
\hline & $\mathrm{HQ}_{\text {inhalation }}$ & 0.00000 & 0.00000 & 0.00000 & 0.00000 & 0.00000 & 0.00000 & 0.00000 & \\
\hline & $\mathrm{HI}$ & 0.31070 & 0.60943 & 1.41826 & 0.40216 & 0.00925 & 0.08174 & 0.30477 & 3.13632 \\
\hline \multirow[t]{4}{*}{ Agricultural zone } & $H Q_{\text {ingestion }}$ & 0.23024 & 0.00253 & 0.99818 & 0.54009 & 0.00729 & 0.08305 & 0.14676 & \\
\hline & $\mathrm{HQ}_{\text {dermal }}$ & 0.04522 & 0.69692 & 0.39208 & 0.01061 & 0.00212 & 0.00431 & 0.00576 & \\
\hline & $\mathrm{HQ}_{\text {inhalation }}$ & 0.00000 & 0.00000 & 0.00000 & 0.00000 & 0.00000 & 0.00000 & 0.00000 & \\
\hline & $\mathrm{HI}$ & 0.27546 & 0.69945 & 1.39027 & 0.55069 & 0.00941 & 0.08736 & 0.15253 & 3.16516 \\
\hline \multirow[t]{4}{*}{ Road zone } & $H Q_{\text {ingestion }}$ & 0.2159 & 0.0032 & 1.1023 & 0.6358 & 0.0081 & 0.1678 & 0.1777 & \\
\hline & $\mathrm{HQ}_{\text {sermal }}$ & 0.04241 & 0.88945 & 0.43297 & 0.01249 & 0.00236 & 0.00871 & 0.00698 & \\
\hline & $\mathrm{HQ}_{\text {inhalation }}$ & 0.00000 & 0.00000 & 0.00000 & 0.00000 & 0.00000 & 0.00000 & 0.00000 & \\
\hline & $\mathrm{HI}$ & 0.2583 & 0.8927 & 1.5352 & 0.6483 & 0.0105 & 0.1765 & 0.1847 & 3.70622 \\
\hline
\end{tabular}

\section{Conclusion}

This study investigated for the first time the level of multi- metallic contamination in Arzew, one of the biggest petroleum and industrial platform of Algeria, where more than 100,000 inhabitants coexist with these activities. The distribution patterns of MTE revealed the impact of industrial and human activities on MTE in the topsoils of the study area. Several hotspots contaminated by $\mathrm{As}, \mathrm{Cr}, \mathrm{Pb}$ and $\mathrm{Zn}$ have been detected in the road traffic zone but also close to the beach and the harbour. A particular attention should be paid also on the presence of high level of As in the agriculture area. Whereas ecological risk seem to be moderate in almost all the areas, the health risk is high in the whole areas, especially when considering $\mathrm{Cr}$ but also the sum of MTE concentrations. 
This study reveals thus a multi-metallic contamination over a large surface in Arzew and a hazard to human and ecosystem health, resulting from chaotic expansion of industries and absence of planning. It highlights the urgent need to strengthen petrochemical regulations in order to protect residents from MTE discharges into Arzew' environment.

Acknowledgements The funding of this study primarily originated from the PROFAS B+ Research Program of the French Ministry of Europe and Foreign Affairs.

\section{Conflicts of interest}

The authors declare that they have no conflict of interest.

\section{References}

Abraham J, Kim Dowling D, Florentine S (2018) Assessment of potentially toxic metal contamination in the soils of a legacy mine site in Central Victoria, Australia. Chemosphere 192:122-132. https://doi.org/10.1016/j.chemosphere.2017.10.150

Aden M., Na Ubol R, Knorr M, Husson J, Euvrard M. (2017) Efficient removal of nickel(II) salts from aqueous solution using carboxymethylchitosan-coated silica particles as adsorbent. Carbohydrate Polymers 173:372-382.

http://dx.doi.org/10.1016/j.carbpol.2017.05.090

AFNOR (Agence Française de NORmalisation), 1996. Qualité des sols. Recueil de normes Françaises 1996. AFNOR, Paris.

Arab M, Bracene R, Roure F, Zazoun RS, Mahdjoub Y, Badji R (2015). Source rocks and related petroleum systems of the Chelif Basin, (western Tellian domain, north Algeria). Marine and Petroleum Geology 64:363-385.

http://dx.doi.org/10.1016/j.marpetgeo.2015.03.017

Barraza F, Maurice L, Uzu G, Becerra S, López F, Ochoa-Herrera V, Ruales J, Schreck E (2018) Distribution, contents and health risk assessment of metal(loid)s in small-scale farms in the Ecuadorian Amazon: An insight into impacts of oil activities. Science of the Total Environment. 622-623:106-120. https://doi.org/10.1016/j.scitotenv.2017.11.24

Bermudez GM, Jasan R, Pla R, Pignata ML (2011). Heavy metal and trace element concentrations in wheat grains: assessment of potential non-carcinogenic health hazard through their consumption. J. Hazard. Mater. 193:264-271.

Broadway A, Cave MR, Wragg J, Fordyce FM, Bewley RJF, Graham MC, Ngwenya BT, Farmer JG (2010) Determination of the bioaccessibility of chromium in Glasgow soil and the implications for human health risk assessment. Science of the Total Environment 409:267277

doi:10.1016/j.scitotenv.2010.09.007

Cao Z, Wang M, Chen Q, Zhang Y, Dong W, Yang T, Yan G, Zhang X, Pi Y, Xi B, Bu Q (2018). Preliminary assessment on exposure of four typical populations to potentially toxic 
metals by means of skin wipes under the influence of haze pollution. Science of the Total Environment 613-614:886-893. https://doi.org/10.1016/j.scitotenv.2017.09.181

Chen L, Zhou S, Shi Y, Wang C, Li B, Li Y, Wu S (2018) Heavy metals in food crops, soil, and water in the Lihe River Watershed of the Taihu Region and their potential health risks when ingested. Science of the Total Environment, 615:141-149.

https://doi.org/10.1016/j.scitotenv.2017.09.230

CNEMC (China National Environmental Monitoring Center), 1990. Background Concentrations of Elements in Soils of China. Chinese Environment Science Press, Beijing (in Chinese)

Dauvin JC, Bakalem A, Baffreau A, Grimes S (2017) Benthic ecological status of Algerian harbours. Marine Pollution Bulletin, 125, 378-388.

http://dx.doi.org/10.1016/j.marpolbul.2017.09.049

Doumergue F and Ficheur E (1908). - Carte géologique de l'Algérie 1/50 000, feuille Oran (1ère éd.).

Håkanson L (1980) An Ecological Risk Index for aquatic pollution control: a sedimentological approach. Water Res. 14:975-1001.

Kampeerawipakorn O, Navasumrit P, Settachana D, Promvijit J, Hunsonti P, Parnlob V, Nakngama N, Choonvisase S, Chotikapukana P, Chanchaeamsai S, Ruchirawat M (2017) Health risk evaluation in a population exposed to chemical releases from a petrochemical complex in Thailand. Environmental Research 152:207-213.

http://dx.doi.org/10.1016/j.envres.2016.10.004

Karim Z, Qureshi BA, Mumtaz M (2015) Geochemical baseline determination and pollution assessment of heavy metals in urban soils of Karachi, Pakistan. Ecological Indicators, 48: 358-364. http://dx.doi.org/10.1016/j.ecolind.2014.08.032

Karri V, Kumar V, Ramos D, Oliveira E, Schuhmacher M (2018) An in vitro cytotoxic approach to assess the toxicity of heavy metals and their binary mixtures on hippocampal HT22 cell line. Toxicology Letters 282:25-36. http://dx.doi.org/10.1016/j.toxlet.2017.10.002

Kossowska B, Dudka I, Gancarz R, Antonowicz-Juchniewicz J (2013) Application of classic epidemiological studies and proteomics in research of occupational and environmental exposure to lead, cadmium and arsenic. International Journal of Hygiene and Environmental Health 216:1-7. doi:10.1016/j.ijheh.2012.03.002

Leyssens L, Vinck B, Van Der Straeten C, Wuyts F, Maesa L (2017) Cobalt toxicity in humans - A review of the potential sources and systemic health effects. Toxicology, 387:4356. http://dx.doi.org/10.1016/j.tox.2017.05.015

Maas S, Scheifler R, Benslama M, Crini N, Lucot E, Brahmia Z, Benyacoub S, Giraudoux P (2010). Spatial distribution of heavy metal concentrations in urban, suburban and agricultural soils in a Mediterranean city of Algeria. Environmental Pollution, 158:2294-2301.

Men C, Liu R, Xu F, Wang Q, Guo L, Shen Z (2018). Pollution characteristics, risk assessment, and source apportionment of heavy metals in road dust in Beijing, China. Science of the Total Environment 612:138-147.

http://dx.doi.org/10.1016/j.scitotenv.2017.08.123 
Morse N, Walter MT, Osmond D, Hunt W (2016) Roadside soils show low plant available zinc and copper concentrations. Environmental Pollution 209:30-37.

http://dx.doi.org/10.1016/j.envpol.2015.11.011

Mousavia SM, Motesharezadeh B, Hosseini HM, Alikhania H, Zolfaghari AA (2018) Rootinduced changes of $\mathrm{Zn}$ and $\mathrm{Pb}$ dynamics in the rhizosphere of sunflower with different plant growth promoting treatments in a heavily contaminated soil. Ecotoxicology and Environmental Safety 147:206-216.

http://dx.doi.org/10.1016/j.ecoenv.2017.08.045

Mulware SJ (2013) Trace elements and carcinogenicity: a subject in review. 3 Biotech 3: 8596. https://doi.org/10.1007/s13205-012-0072-6

Pathak AK, Kumar R, Kumar P, Yadav S (2015). Sources apportionment and spatiotemporal changes in metal pollution in surface and sub-surface soils of a mixed type industrial area in India. J. Geochem. Explor. 159:169-177.

Prashanth L, Kattapagari KK, Chitturi RT, Baddam VR, Prasad, LK (2015) A review on role of essential trace elements in health and disease. J. NTR. Univ. Health. Sci., 4:75-85.

Solgi E, Sheikhzadeha H, Solgi M (2018) Role of irrigation water, inorganic and organic fertilizers in soil and crop contamination by potentially hazardous elements in intensive farming systems: Case study from Moghan agro-industry, Iran. Journal of Geochemical Exploration, 185:74-80. https://doi.org/10.1016/j.gexplo.2017.11.008

Tang Z, Chai M, Cheng J, Jin J, Yang Y, Nie Z, Huang Q, Li Y (2017) Contamination and health risks of heavy metals in street dust from a coalmining city in eastern China. Ecotoxicology and Environmental Safety 138:83-91.

Thorpe A, Harrison RM (2008) Sources and properties of non-exhaust particulate matter from road traffic: a review. Sci. Total Environ. 400:270-282.

Turner A, Lewis M (2018). Lead and other heavy metals in soils impacted by exterior legacy paint in residential areas of south west England. Science of the Total Environment 619620:1206-1213.

https://doi.org/10.1016/j.scitotenv.2017.11.041

U.S Environmental Protection Agency (EPA). (2014) Child-specific exposure scenarios examples. National Center for Environmental Assessment, Washington, D.C.; EPA/600/R14/217F. Available from the National Information Service, Springfield, VA and online athtpp://www.epa.gov/ncaa

U.S. Environmental Protection Agency (EPA). (2011) Exposure Factors Handbook: 2011 Edition. National Center for Environmental Assessment, Washington, DC; EPA/600/R09/052F. Available from the National Technical Information Service, Springfield, VA, and online at http://www.epa.gov/ncea/efh

U.S. Environmental Protection Agency (EPA). (1989) Risk Assessment Guidance for Superfund Volume 1: Human Health Evaluation Manual (Part A) Office of Emergency and Remedial Response; Washington, DC, EPA/540/1-89/002.

Zhou Y, Niu L, Liu K, Yin S, Liu W (2018) Arsenic in agricultural soils across China: Distribution pattern, accumulation trend, influencing factors, and risk assessment. Science of the Total Environment. 616-617:156-163.

https://doi.org/10.1016/j.scitotenv.2017.10.232 